\title{
Faktor Penentu Produksi pada Perkebunan Rakyat Kelapa Sawit di Kabupaten Mamuju Utara
}

\author{
Determining Factors of Production in Palm Oil Palm \\ Plantation in North Mamuju District
}

\author{
*Dimas Deworo Puruhito \\ Mahasiswa Pascasarjana Fakultas Pertanian, Universitas Gadjah Mada \\ Jamhari, Slamet Hartono, dan Irham \\ Fakultas Pertanian Universitas Gadjah Mada
}

Submitted: 19-09-2018; Revised: 11-02-2019; Accepted: 11-02-2019

\begin{abstract}
There are three patterns of smallholder oil palm plantation in North Mamuju regency, ie plasma, IGA (Income Generating Activity), and mandiri (independent). Independent smallholder plantations are plantations managed by the community themselves without the involvement of others. While the partnership patterns can be divided into plasma and IGA. The partnership is a form of fostering of smallholders plantations by large private plantation in this area. This study aims to determine the amount of oil palm production on smallholder plantations and the factors that affect.This research was conducted in North Mamuju Regency, West Sulawesi Province which has the widest smallholder oil palm plantation in Sulawesi Island with various pattern. Four villages in two sub-districts were chosen purposively consideration with having three patterns of smallholder plantations. Farmer samples were taken using the snowball method after stratification of the pattern was carried out. Data analysis was performed with Cobb-Doulas function model in the normalized logarithm, using Eviews 6 software. These findings are the average production of $56,840 \mathrm{~kg}$, with productivity of $20,300 \mathrm{~kg} / \mathrm{ha}$. Input of land area, NPK fertilizer, age of oil palm crops, outside family labor, frequency of estate sanitation and distance of estate to river is the determinant input to production. Input land area is found as the most elastic input. However, land use for oil palm plantations should still refer to existing legislation.
\end{abstract}

Keywords: Factor; Oil palm; Plantations; Production; Smallholder.

\begin{abstract}
ABSTRAK
Terdapat tiga pola perkebunan rakyat kelapa sawit di Kabupaten Mamuju Utara, yakni pola plasma, IGA (Income Generating Activity), dan mandiri/swadaya. Perkebunan rakyat mandiri/swadaya adalah perkebunan yang dikelola masyarakat sendiri tanpa keterlibatan pihak lain. Sedangkan perkebunan plasma dan IGA merupakan bentuk kemitraan dengan perkebunan besar. Tujuan penelitian ini untuk mengetahui seberapa besar produksi kelapa sawit perkebunan rakyat dan faktor-faktor yang mempengaruhinya. Kabupaten Mamuju Utara dipilih sebagai lokasi penelitian karena memiliki
\end{abstract}

*Corresponding author: dimasdeworopuruhito@gmail.com

Copyright (c) 2019 THE AUTHOR(S). This article is distributed under a Creative Commons Attribution-Share Alike 4.0 International license. Jurnal Teknosains is published by the Graduate School of Universitas Gadjah Mada. 
perkebunan rakyat kelapa sawit terluas di Pulau Sulawesi dengan berbagai pola pengusahaan. Empat desa di dua kecamatan yang memiliki ketiga pola pengusahaan dipilih sebagai sampel lokasi. Sampel petani diambil dengan metode snowball setelah dilakukan stratifikasi pola pengusahaan. Analisis data menggunakan model fungsi produksi Cobb-Doulas dalam bentuk logaritma yang dinormalkan, dengan software Eviews 6. Hasil penelitian menunjukkan produksi sebesar $56.840 \mathrm{~kg}$, dengan produktivitas sebesar $20.300 \mathrm{~kg} / \mathrm{ha}$. Input luas lahan, pupuk NPK, umur tanaman kelapa sawit, tenaga kerja luar keluarga, frekuensi sanitasi kebun dan jarak kebun ke sungai merupakan input penentu terhadap produksi. Meskipun lahan merupakan input yang paling elastis, namun pemanfaatan lahan bagi perkebunan kelapa sawit tetap harus mengacu pada peraturan perundangan yang berlaku.

Kata Kunci: Faktor; Kelapa sawit; Pekebun rakyat; Perkebunan; produksi.

\section{PENGANTAR}

Kelapa sawit adalah komoditas perkebunan unggulan di Indonesia. Beberapa peran penting dimiliki oleh komoditas ini bagi kemajuan perekonomian nasional, diantaranya sebagai penghasil devisa negara, sumber pendapatan petani, penciptaan lapangan kerja, pendorong kegiatan agribisnis dan agroindustri di daerah serta pengembangan wilayah. Data statistik menunjukkan pada tahun 2015, dari sekitar 11,30 juta hektar luas areal perkebunan kelapa sawit di Indonesia 40,49 persennya diusahakan dalam bentuk perkebunan rakyat (PR), selebihnya diusahakan oleh perkebunan besar baik perkebunan besar negara (PBN) sebesar 6,64 persen serta perkebunan besar swasta (PBS) sebesar 52,87 persen.

Manajemen produksi di perkebunan kelapa sawit saat ini telah menerapkan praktek budidaya terbaik yang tidak hanya memasukkan unsur teknis budidaya, namun juga memasukkan unsur lingkungan, sosial dan ekonomi baik di on-farm maupun offfarm (Weng, 2005, Anderson, 2008, dan Jelani et al., 2008) Meskipun demikian, produktivitas perkebunan rakyat kelapa sawit baru mencapai 2,81 ton $\mathrm{CPO} /$ ha/tahun, angka ini masih jauh lebih rendah dari rata-rata produktivitas nasional sebesar 3,29 ton CPO/ha/th (Anonim, 2017). Rendahnya produktivitas akan menyebabkan rendahnya penerimaan petani/ pekebun seperti yang terjadi pada perkebunan rakyat karet, Afif, et al., (2016).

Pekebun didefinisikan sebagai perorangan warga negara Indonesia yang melakukan usaha perkebunan dengan skala usaha tidak mencapai skala tertentu. Skala tertentu bagi perkebunan rakyat adalah kurang atau sama dengan 25 hektar. Perkebunan tersebut diusahakan perorangan sebagai petani pada tanah milik. Sama halnya dengan perkebunan besar, perkebunan rakyat diharapkan juga mampu menerapkan prinsip-prinsip perkebunan dengan benar dan berkelanjutan. Berkelanjutan secara sosial, ekonomi dan lingkungan (Ditjenbun, 2012).

Jumlah dan kombinasi faktor produksi yang digunakan akan mempengaruhi banyaknya hasil produksi yang dihasilkan oleh suatu proses produksi. Petani akan berusaha untuk selalu efisien dalam mengalokasikan input yang akan digunakan dalam usahataninya untuk memperoleh produksi yang maksimal. Hubungan jumlah input yang digunakan dengan output yang dihasilkan dapat dinyatakan dalam suatu fungsi produksi. Fungsi produksi merupakan hubungan antara jumlah input yang diperlukan dan jumlah output yang dapat diperoleh (Pindyck dan Rubinfield, 2001; Samuelson dan Nordhaus, 2001), fungsi produksi menggambarkan keluaran maksimal yang dapat diproduksi dengan jumlah masukan tertentu dalam jumlah minimum yang diperlukan untuk memproduksi satu tingkat keluaran tertentu (Pappas dan Hirsehiy, 1995).

Analisis fungsi produksi dapat digunakan untuk menduga hubungan kuantitatif antar input dan output tersebut (Soekartawi, 1994). Menurut Bishop dan Toussaint (1986), fungsi produksi merupakan suatu hubungan matematis yang menggambarkan bahwa jumlah hasil produksi tertentu tergantung pada jumlah input tertentu yang digunakan, sehingga suatu fungsi produksi memberikan keterangan mengenai jumlah output yang 
mungkin diharapkan apabila input tertentu dikombinasikan dalam suatu cara yang khusus.

Doll dan Orazem (1984) menyatakan dalam proses produksi terdapat dua jenis input , yaitu input variabel dan input tetap. Input variabel merupakan input yang habis dipakai dalam satu periode produksi, sedangkan input tetap adalah input yang tidak habis dipakai dalam satu periode produksi. Guna meningkatkan produktivitas perkebunan rakyat, maka ditempuhlah berbagai upaya perbaikan kinerja perkebunan rakyat, salah satunya melalui model kemitraan antara perkebunan besar (inti) dan perkebunan rakyat. Pengembangan pola kemitraan sejalan dengan terbitnya Peraturan Menteri Pertanian (Permentan) No. 33 tentang Revitalisasi Perkebunan pada pertengahan tahun 2006. Melalui permentan tersebut telah dilakukan upaya-upaya percepatan pengembangan perkebunan rakyat baik melalui perluasan, peremajaan dan rehabilitasi tanaman perkebunan yang didukung kredit investasi perbankan dan subsidi bunga oleh pemerintah yang melibatkan perusahaan perkebunan sebagai mitra dalam membangun kebun, mengolah dan memasarkan hasil. Komoditas yang dikembangkan antara lain; kelapa sawit, karet dan kakao, dengan pertimbangan (i) komoditas yang dikembangkan memiliki peran strategis sebagai sumber pendapatan masyarakat, (ii) komoditi tersebut memiliki prospek pasar dalam negeri dan ekspor, (iii) mampu menyerap tenaga kerja baru, serta (iv) memiliki peranan dalam pelestarian fungsi lingkungan hidup (Biro Data Indonesia, 2014). Menurut Kemenpertanian (2013), perusahaan Inti Rakyat adalah pola untuk mewujudkan suatu perpaduan usaha dengan sasaran perbaikan keadaan sosial ekonomi peserta dan didukung oleh suatu sistem pengelolaan usaha dengan memadukan berbagai kegiatan produksi, pengelolaan dan pemasaran dengan menggunakan perusahaan besar sebagai inti dalam suatu sistem kerja sama yang saling menguntungkan. Demikian pula yang terjadi di perkebunan rakyat kelapa sawit, model kemitraan yang dilakukan dapat berupa pola plasma maupun pola kemitraan lain yang bertujuan untuk meningkatkan kinerja perkebunan rakyat kelapa sawit, dan keberlanjutan industri kelapa sawit. Keberlanjutan terhadap aktivitas usahatani menurut Lebacq bahwa harus memenuhi paling tidak tiga dimensi keberlanjutan, yaitu keberlanjutan lingkungan, keberlanjutan ekonomi dan keberlanjutan social (Lebacq dkk., 2013).

Kabupaten Mamuju Utara, merupakan kabupaten dengan luasan perkebunan rakyat kelapa sawit terbesar di Pulau Sulawesi. Terdapat tiga pola perkebunan rakyat kelapa sawit di Kabupaten Mamuju Utara, yakni pola plasma, pola IGA (Income Generating Activity), dan pola mandiri/swadaya. Perkebunan rakyat mandiri/swadaya adalah perkebunan yang dikelola masyarakat sendiri tanpa keterlibatan pihak lain. Sedangkan kemitraan dapat dibedakan menjadi pola plasma dan pola IGA. Perkebunan besar swasta selain membangun kebun inti, juga melakukan pembangunan dan pembinaan pada perkebunan rakyat melalui program plasma/PIR-Trans tahun 1991/1992 serta program IGA sejak tahun 2006/2007. Adanya pola kemitraan diharapkan mampu mengurangi gap antara perkebunan besar dan perkebunan rakyat baik dalam hal teknis, ekonomis, dan sosial, yang akan menjamin keberlanjutan industri kelapa sawit itu sendiri. Berdasarkan uraian tersebut di atas, tujuan dari penelitian ini adalah untuk mengestimasi berapa besar produksi dan faktor-faktor yang mempengaruhi produksi pada perkebunan rakyat kelapa sawit di Kabupaten Mamuju Utara.

\section{Metode}

Penelitian ini dilakukan di Kabupaten Mamuju Utara Propinsi Sulawesi Barat yang memiliki areal perkebunan rakyat kelapa sawit terluas di Pulau Sulawesi. Selain itu, di Kabupaten Mamuju Utara terdapat berbagai pola pengusahaan perkebunan rakyat kelapa sawit, seperti model kemitraan (pola IGA dan plasma) juga model mandiri (swadaya). Empat desa di dua kecamatan dipilih secara purposive sebagai lokasi penelitian dengan pertimbangan di wilayah tersebut terdapat ketiga pola 
pengusahaan perkebunan rakyat. Keempat desa tersebut adalah Desa Tikke dan Lariang di Kecamatan Tikke Raya, serta Desa Pedanda dan Martasari di Kecamatan Pedongga. Sampel petani diambil dengan metode snowball setelah terlebih dahulu dilakukan stratifikasi pada setiap pola pengusahaan. Terpilih 35 petani plasma, 70 petani IGA, dan 55 petani mandiri/ swadaya.

Produksi merupakan suatu proses yang mengubah faktor-faktor (input) menjadi suatu produk/output (Downey dan Erickson, 1992). Tinggi rendahnya produksi tergantung pada keputusan petani, berapa jumlah sumber daya (input) yang akan digunakan, berapa luas tanah yang dipakai, berapa banyak bibit, pupuk, pestisida, tenaga kerja dan lain-lain.

Secara umum, bentuk matematika dari fungsi produksi adalah

$\mathrm{Y}=\mathrm{f}\left(\mathrm{x}_{1^{\prime}}, \mathrm{x}_{2^{\prime}}, \mathrm{x}_{3^{\prime}} \ldots \mathrm{x}_{\mathrm{i}}\right)$.

Di mana,

$$
\begin{aligned}
Y= & \text { output } \\
x_{i}= & \text { input } / \text { faktor produksi yang } \\
& \text { digunakan dalam proses produksi } \\
& \text { dengan } \mathrm{i}=1,2,3, \ldots, \text { dst (Downey } \\
& \text { dan Erickson, 1992). }
\end{aligned}
$$

Guna mengestimasi faktor-faktor yang berpengaruh dalam produksi perkebunan rakyat kelapa sawit digunakan model fungsi Cobb-Doulas dalam bentuk logaritma yang dinormalkan (Yotopoulus and Nugent, 1976; Debertin, 1986; Nicholson, 1998), yaitu :

$$
\begin{aligned}
\operatorname{Ln} Y= & b_{0}+b_{1} \ln X_{1}+b_{2} \ln X_{2}+b_{3} \ln X_{3}+b_{4} \ln X_{4} \\
& +b_{5} \ln X_{5}+b_{6} \ln X_{6}+b_{7} \ln X_{7}+b_{8} \ln X_{8}+ \\
& b_{9} \ln X_{9}+b_{10} D_{1}+\varepsilon_{i}
\end{aligned}
$$

Di mana :

$$
\begin{aligned}
\mathrm{Y} & =\text { produksi TBS (ton) } \\
\mathrm{X}_{1} & =\text { luas lahan (ha) } \\
\mathrm{X}_{2} & =\text { penggunaan pupuk urea }(\mathrm{kg}) \\
\mathrm{X}_{3} & =\text { penggunaan pupuk NPK }(\mathrm{kg}) \\
\mathrm{X}_{4} & =\text { penggunaan herbisida }(\mathrm{l}) \\
X_{5}= & \text { penggunaan TK luar keluarga } \\
& \text { (HOK) } \\
X_{6}= & \text { penggunaan TK dalam keluarga } \\
& \text { (HOK) } \\
X_{7}= & \text { umur tanaman (th) } \\
X_{8}= & \text { frekuensi sanitasi kebun (kali) } \\
X_{9}= & \text { jarak kebun ke sungai terdekat }
\end{aligned}
$$

$(\mathrm{km})$

$\mathrm{D}_{1} \quad=$ peubah dummy jenis lahan, di mana $1=$ lahan mineral, dan $0=$ lahan gambut

$\mathrm{b}_{0} \quad=$ intersep

bi $=$ koefisien regresi parameter penduga dengan $i=1,2,3, \ldots, 10$

$\varepsilon_{\mathrm{i}} \quad=$ error term

Pengujian hipotesisnya adalah :

$\mathrm{H}_{\mathrm{o}} \quad: \mathrm{b}_{\mathrm{i}}=0$

$\mathrm{H}_{1}^{\mathrm{o}} \quad: \mathrm{b}_{\mathrm{i}} \neq 0$

Jika $\mathrm{H}_{0}$ diterima, artinya masing-masing variabel bebas tidak ada yang berpengaruh terhadap variabel terikatnya di dalam model. Sebaliknya jika $\mathrm{H}_{0}$ ditolak, memberi makna bahwa setiap variabel bebas memberi pengaruh pada variabel terikatnya, dalam hal ini adalah produksi tandan buah segar (TBS) kelapa sawit perekebunan rakyat. Bentuk matematika dari pengujian hipotesisnya adalahKriteria pengujiannya, menggunakan uji dua arah, di mana :

$\mathrm{t}_{\text {hitung }}=(\mathrm{bi}-\beta \mathrm{i}) / \mathrm{Sbi}=(\mathrm{bi}-0) / \mathrm{Sbi}=\mathrm{b}_{\mathrm{i}} / \mathrm{Sb}_{\mathrm{i}}$ dan $\mathrm{t}_{\text {tabel }}=\mathrm{t}(\mathrm{a} / 2, \mathrm{n}-\mathrm{k})$

\section{Di mana :}

bi : koefisien regresi masing-masing variabel bebas

$\beta \quad$ : parameter populasi (koefisien regresi populasi) dihipotesisiskan $=0$.

$\mathrm{Sb}_{\mathrm{i}} \quad$ : simpangan baku koefisien regresi masing-masing variabel bebas

n : jumlah sampel

k : jumlah variabel bebas di dalam persamaan regresi

Jika $t_{\text {hitung }}>t_{\text {tabel }}$ berarti $\mathrm{H}_{0}$ ditolak, dan jika $t_{\text {hitung }} \leq t_{\text {tabel }}$ berarti $\mathrm{H}_{0}$ diterima.

Software yang digunakan untuk analisis penelitian ini adalah Eviews 6.

\section{HASIL DAN PEMBAHASAN}

Secara umum kondisi kebun petani, terbagi menjadi lahan gambut dan lahan mineral. Jumlah petani di lahan mineral sebanyak 100 orang dan petani di lahan gambut sebanyak 60 orang. Umur rata-rata tanaman kelapa sawit 
adalah 12 tahun. Rata-rata frekuensi sanitasi kebun adalah $3 \mathrm{kali} / \mathrm{th}$. Pada umumnya, lahanlahan plasma terletak di daerah rendahan yang dekat dengan sungai dibandingkan dengan lahan-lahan IGA maupun mandiri. Rata-rata jarak kebun ke sungai adalah 2,5 km.

Rata-rata kepemilikan lahan oleh petani adalah 2,8 hektar, dengan luas lahan minimum 1 hektar dan maksimum 10 hektar. Masingmasing petani pada pola plasma memiliki lahan seluas dua hektar karena secara bersamasama mereka mendapatkan lahan melalui program PIR Transmigrasi pada tahun 19941995. Penggunaan pupuk urea, NPK, dan herbisida adalah sebesar $691 \mathrm{~kg}, 1.469 \mathrm{~kg}$, dan 101 , sedangkan penggunaan tenaga kerja luar keluarga sebesar $18 \mathrm{HKO}$ dan dalam keluarga sebesar $8 \mathrm{HKO}$.

Produksi perkebunan rakyat kelapa sawit berupa tandan buah segar (TBS). Rata-rata produksi perkebunan rakyat kelapa sawit adalah sebesar $56.840 \mathrm{~kg}$, dengan produktivitas sebesar $20.300 \mathrm{~kg} / \mathrm{ha}$.

Hasil estimasi pada Tabel 1 menunjukkan bahwa persamaan fungsi logaritma natural produksi pekebunan rakyat kelapa sawit memiliki nilai koefisien determinasi $\left(\mathrm{R}^{2}\right)$ $86,84 \%$. Hal ini menunjukkan $86,84 \%$ variasi produksi dapat dijelaskan oleh variasi pada variabel bebasnya, seperti luas lahan, pupuk urea, pupuk NPK, herbisida, tenaga kerja, umur tanaman, frekuensi sanitasi kebun, jarak kebun dengan sungai, serta jenis tanah, sedangkan sisanya $(13,16 \%)$ dapat dijelaskan oleh variasi yang terjadi pada variabel di luar model. Untuk mengetahui pengaruh dari variabel bebas secara bersama-sama terhadap variabel terikat digunakan uji F. Nilai F-statistic sebesar 98,2986 lebih besar dari $\mathrm{F}$ tabel pada $\alpha=0,01$ $(2,3611)$ memberi arti bahwa seluruh variabel bebas secara berama-sama berpengaruh terhadap produksi perkebunan rakyat kelapa sawit. Uji asumsi klasik yang dilakukan pada pendugaan fungsi produksi tidak ditemukan adanya multikolineritas dan heterokedastisitas.

Pengaruh dari masing-masing variabel bebas (individual) terhadap variabel terikatnya dapat dicari dengan menggunakan uji $t$. Dari hasil estimasi pada Tabel 1, luas lahan, penggunaan pupuk NPK, dan umur tanaman kelapa sawit berpengaruh nyata terhadap tingkat produksi tandan buah segar (TBS) kelapa sawit di perkebunan rakyat dengan tingkat signifikansi $a=0,01$. Penggunaan tenaga kerja luar keluarga, frekuensi sanitasi kebun dan jarak kebun ke sungai secara statistik berpengaruh nyata terhadap produksi TBS pada $\alpha=0,05$, sedangkan penggunaan tenaga kerja dari dalam keluarga berpengaruh nyata pada $a=0,1$. Lahan merupakan faktor produksi yang paling elastis, hal ini dapat dilihat dari nilai koefisiennya yang paling besar di antara faktor produksi lainnya, yaitu sebesar 0,8725 . Artinya jika luas lahan bertambah 1 persen, maka produksi TBS kelapa sawit akan meningkat sebesar 0,8725 persen. Selama ini Indonesia masih dianggap sebagai produsen terbesar kelapa sawit yang berasal dari perluasan areal perkebunan kelapa sawit. Hal ini berbeda dengan negara Malaysia yang juga dikenal sebagai produsen kelapa sawit yang berasal dari peningkatan produktivitas lahannya.

Pupuk NPK bagi pekebun kelapa sawit merupakan faktor produksi yang wajib digunakan dalam kegiatan budidaya. Pupuk NPK mengandung unsur makro lengkap yang diperlukan oleh tanaman kelapa sawit baik untuk fase vegetatif maupun fase generatif. Ketidaksesuaian dosis dan waktu dalam aplikasi pemupukan akan mempengaruhi produksi TBS kelapa sawit. Koefisien regresi pupuk NPK sebesar 0,0849 artinya jika terjadi penambahan pupuk NPK sebesar 1 persen akan meningkatkan produksi TBS kelapa sawit sebesar 0,0849 persen.

Tanaman kelapa sawit memiliki rentang waktu yang lama untuk dapat menjadi tanaman menghasilkan (TM). Diperlukan waktu sekitar 4 tahun mulai dari perkecambahan hingga mampu berbuah, tanaman di usia ini disebut dengan tanaman belum menghasilkan (TBM). Setelah tahun keempat tanaman berangsurangsur meningkat produksinya hingga sekitar 
umur 17 tahun dan akan berangsur-angsur turun produksinya hingga perlu diremajakan pada usia 25 tahun. Namun demikian, banyak pekebun sawit yang masih mempertahankan tanaman kelapa sawit yang sudah tua karena sayang untuk meremajakannya. Adanya tenggat waktu yang cukup lama untuk menghasilkan/berproduksi, juga membuat pekebun harus berpikir ulang untuk melakukan peremajaan tanaman (replanting). Nilai koefisien regresi umur tanaman kelapa sawit sebesar 0,2619, artinya jika umur tanaman meningkat 1 persen maka produksi TBS kelapa sawit akan meningkat sebesar 0,2619 persen. Rata-rata umur tanaman kelapa sawit adalah 12 tahun hal ini menunjukkan bahwa kelapa sawit rakyat masih sangat produktif dalam jangka panjang.

Tenaga kerja yang berasal dari luar keluarga memiliki peran penting dalam kegiatan budidaya kelapa sawit di perkebunan rakyat. Tenaga kerja dari luar keluarga umumnya digunakan untuk kegiatan perawatan tanaman dan panen. Seringkali kegiatan rawat dan panen terlambat dilakukan akibat tidak adanya tenaga kerja. Hal ini akan menurunkan produksi dan kualitas hasil panen. Nilai koefisien regresi tenaga kerja dari luar keluarga sebesar 0,0133 artinya jika jumlah tenaga kerja dari luar keluarga ditambah 1 persen, maka produksi TBS kelapa sawit akan meningkat sebesar 0,0133 persen.

Sanitasi kebun dilakukan untuk menjaga lingkungan perkebunan rakyat kelapa sawit bersih dan mengurangi risiko gangguan hama, penyakit serta gulma yang dapat mengancam produksi kelapa sawit. Kegiatan sanitasi kebun meliputi pembersihan piringan, pembersihan pasar pikul, serta pembersihan tempat pengumpulan hasil (TPH). Namun demikian, akibat penanganan yang tidak sesuai rekomendasi dan sering terjadi banjir di wilayah ini, menyebabkan timbunan (rumpukan) hasil sanitasi yang seharusnya diletakkan pada gawangan mati, menjadi menyebar di areal perkebunan kelapa sawit. Selain lingkungan kebun menjadi kotor, hal ini juga dapat mengganggu aktivitas perawatan tanaman, panen, serta pengangkutan hasil.

Kecuali frekuensi sanitasi kebun, tanda koefisien variabel telah sesuai dengan harapan. Koefisien variabel frekuensi sanitasi kebun bertanda negatif mengingat hasil rumpukan pembersihan kebun belum mendapat penanganan yang semestinya di gawangan mati, sehingga jika terjadi banjir, rumpukan yang ada bisa menyebar ke seluruh kebun yang menyebabkan kondisi kebun kurang optimal. Hal inilah yang menyebabkan tanda koefisien regresi sanitasi kebun bertanda negatif. Besaran koefisien frekuensi sanitasi kebun adalah -0,1762 yang artinya apabila frekuensi sanitasi kebun ditingkatkan sebesar 1 persen akan menurunkan produksi TBS kelapa sawit sebesar 0,1762 persen. Meski berlawanan dengan tanda harapan, bukan berarti frekuensi sanitasi kebun harus dikurangi/ditiadakan. Frekuensi sanitasi kebun perlu dilakukan minimal 2 kali/tahun sesuai rekomendasi yang ada, hanya saja sampah/limbah hasil sanitasi perlu mendapat penanganan yang tepat agar tidak malah mengotori kebun dan mengganggu aktivitas pekerja. Jika hal tersebut dapat tertangani dengan baik, maka frekuensi sanitasi akan mampu meningkatkan produksi TBS kelapa sawit di perkebunan rakyat.

Jarak kebun ke sungai besar terdekat akan sangat berpengaruh terhadap sering tidaknya kebun petani mengalami banjir. Jika terjadi banjir segala kegiatan perawatan tanaman dan panen akan terganggu. Demikian pula pasca banjir, kondisi kebun akan menjadi kotor dan mengganggu kinerja tenaga kerja. Ratarata jarak kebun ke sungai besar sejauh 2,55 $\mathrm{km}$. Koefisien regresi jarak kebun ke sungai sebesar 0,1017 artinya jika jarak kebun ke sungai bertambah 1 persen, maka produksi TBS kelapa sawit akan meningkat sebesar 0,1017 persen. Jika saja daerah aliran sungai (DAS) terpelihara dengan baik, maka potensi banjir dapat ditekan. Namun kenyataan di lapangan menunjukkan bahwa DAS di wilayah ini juga telah banyak berubah menjadi perkebunan kelapa sawit. 
Tabel 1

Estimasi Model Fungsi Produksi Cobb-Douglas dengan Metode OLS pada Perkebunan Rakyat Kelapa Sawit

\begin{tabular}{llccc}
\hline \multicolumn{1}{c}{ Variabel } & Tanda harapan & Koefisien & Standar eror & t-rasio \\
\hline Konstanta & + & $7257,5680^{* * *}$ & 0,1586 & 56,0496 \\
Lahan & + & $0,8725^{* * *}$ & 0,0555 & 15,7134 \\
Urea & + & $0,0009_{\text {ns }}$ & 0,0046 & 0,1859 \\
NPK & + & $0,0849^{* * *}$ & 0,0145 & 5,8450 \\
Herbisida & + & $0,0120^{\text {ns }}$ & 0,0075 & 1,5915 \\
TngKerja Luar Kelg & + & $0,0133^{* *}$ & 0,0053 & 2,4978 \\
TngKerja Dalam Kelg & + & $0,0096^{*}$ & 0,0054 & 1,7811 \\
Umur Kelapa Sawit & + & $0,2619^{* * *}$ & 0,0739 & 3,5453 \\
Frekuensi Sanitasi & + & $-0,1762^{* *}$ & 0,0860 & $-2,0500$ \\
Jarak kebun-sungai & + & $0,1017^{* *}$ & 0,0393 & 2,5882 \\
Jenis Tanah & + & $0,0087^{\text {ns }}$ & 0,0556 & 0,1575 \\
\hline R-squared & & 0,8684 & & \\
Adj R-squared & & 0,8595 & & \\
F-statistic & 98,2986 & & \\
Prob(F-statistic) & & 0,0000 & & \\
\hline
\end{tabular}

Sumber : : Analisis data primer, 2017.

Keterangan : ***nyata pada a $1 \%{ }^{* *}$ nyata pada $\alpha 5 \%$

*nyata pada a $10 \%{ }^{\text {ns }}$ non signifikan

Tenaga kerja yang berasal dari dalam keluarga memiliki peran bagi kelangsungan perkebunan rakyat kelapa sawit. Meskipun jumlahnya tidak sebanyak tenaga kerja dari luar keluarga, kemampuan mereka masih dibutuhkan di saat terjadi kelangkaan tenaga kerja, seperti saat musim panen dan saat kegiatan pemupukan yang waktunya sangat terbatas dan hampir seluruh kebun melakukan pada saat yang bersamaan. Koefisien regresi dari tenaga kerja dalam keluarga sebesar 0,0096 yang artinya jika penggunaan tenaga kerja dalam keluarga ditambah sebesar 1 persen, maka produksi TBS kelapa sawit akan meningkat sebesar 0,0096 persen. Penggunaan pupuk urea, penggunaan herbisida dan jenis lahan, tidak berpengaruh terhadap produksi TBS kelapa sawit. Kandungan unsur N selain diperoleh dari pupuk urea juga dapat diperoleh dari pupuk NPK, yang relatif jumlahnya lebih banyak digunakan oleh petani pada masingmasing pola pengusahaan, sehingga dapat menyebabkan kurang berpengaruhnya pupuk urea terhadap produksi kelapa sawit.
Penggunaan herbisida tidak berpengaruh nyata terhadap produksi kelapa sawit, dikarenakan usia tanaman kelapa sawit sudah di atas 10 tahun sehingga tajuk tanaman sudah lebar dan membuat intensitas cahaya matahari tidak mengenai areal bawah tajuk tanaman. Hal ini menyebabkan gulma tidak banyak tumbuh di sekitar piringan tanaman dan pengendalian gulma relatif sedikit menggunakan herbisisda.

Jenis lahan di perkebunan rakyat tidak mempengaruhi produksi, hal ini terjadi karena lahan gambut yang asam jika dikelola dengan benar hasilnya tidak kalah dengan lahan mineral. Pada umumnya petani di lahan gambut telah memberikan tambahan kapur dan melakukan pengaturan pengairan di kebun mereka untuk menurunkan tingkat keasaman lahan pada awal-awal penanaman.

Selain itu, nilai dari parameter $b$ menunjukkan elastisitas produksi untuk masing-masing faktor produksi, serta dapat mengukur intensitas penggunaan faktor produksi. Penjumlahan dari nilai keseluruhan $b$ mampu menunjukkan tingkat skala hasil. Nilai dari penjumlahan seluruh parameter $b$ 
dalam model ini adalah sebesar 1,1893, yang artinya perkebunan rakyat kelapa sawit berada pada keadaan increasing return to scale (IRS), hal ini terjadi karena proporsi perubahan output lebih besar dari proporsi perubahan inputnya $(1,1893>1)$. Dalam hal ini produksi kelapa sawit perkebunan rakyat masih layak untuk ditingkatkan dengan menambah input produksinya.

\section{SIMPULAN}

Simpulan dari penelitian ini menunjukkan jika rata-rata produksi perkebunan rakyat kelapa sawit adalah sebesar $56.840 \mathrm{~kg}$, dengan produktivitas sebesar $20.300 \mathrm{~kg} / \mathrm{ha}$. Input luas lahan, penggunaan pupuk NPK, umur tanaman kelapa sawit, penggunaan tenaga kerja luar keluarga, frekuensi sanitasi kebun dan jarak kebun ke sungai mempengaruhi produksi kelapa sawit pada perkebunan rakyat.

Sanitasi kebun tetap perlu dilakukan, tetapi perlu peningkatan pengetahuan dan teknologi yang tepat untuk menangani rumpukan/hasil sanitasi kebun. Input luas lahan merupakan faktor produksi yang paling elastis, meskipun demikian, pemanfaatan lahan bagi perkebunan kelapa sawit sebaiknya tetap mengacu pada peraturan perundangan yang ada.

\section{DAFTAR PUSTAKA}

Afif, M., A., Purwoko., \& N.N., Arianti. 2016. Inequality of Rubber Farmer Household Revenue Distribution in Margo Mulyo Village Pondok Kubang Subdistrict Bengkulu Tengah District. Agrisep, 15 (2) ; 177-187.

Anderson, J.M. 2008. Eco-Friendly Approaches to Sustainable Palm Oil Production. Journal of Oil Palm Research; 127-142.

Biro Data Indonesia. 2014. Persaingan Bisnis Perkebunan Kelapa Sawit di Indonesia 2015. PT. Biro Data Indonesia. Tangerang.

Bishop, C.E., dan W.D. Toussaint. 1986. Pengantar Analisis Ekonomi Pertanian. Diterjemahkan oleh Wisnuaji.
Cetakan kedua. Mutiara Sumber Widya. Jakarta.

Debertin, D.L. 1986. Agricultural Production Economics. Second Edition. McGraw Hill Inc. New York.

Direktorat Jenderal Perkebunan. 2012. Statistik Perkebunan. Direktorat Jenderal Perkebunan Kementerian Pertanian. http://ditjenbun.deptan. go.id/ diunduh 4 Januari 2014.

Direktorat Jenderal Perkebunan. 2017. Sinergi Membangun Perkebunan. Makalah pada Pertemuan Konsolidasi dan Diseminasi Kebijakan Pembangunan Perkebunan Tahun 2017. Yogyakarta, 26 Oktober 2017.

Doll, J.P., dan F. Orazem. 1984. Production Economics, Theory with Application. Second Edition. John Willey Sons IAC. Canada.

Downey, W.D. dan S.P. Erickson. 1992. Agribusiness Management. Second Edition. McGraw_Hill, Inc. USA.

Jelani A.R., A. Hitam, J. Jamak, M. Noor, Y. Gono, and O. Ariffin. 2008. Cantas ${ }^{\mathrm{TM}}$ - A Tool for The Efficient Harvesting of Oil Palm Fresh Fruit Branches. Journal of Oil Palm Research, 20; 548558.

Kementerian Pertanian. 2013. Peraturan Menteri Pertanian Republik Indonesia Nomor 98/Permentan/OT.140/9/2013 tentang Pedoman Perizinan Usaha Perkebunan. Kementerian Pertanian.

Lebacq, T., P.V. Baret, and D. Stilmant. 2013. Sustainability Indicators for Livestock Farming. A review. Agronomy for Sustainable Development, 33; 311-327.

Nicholson, W. 1998. Microeconomic Theory: Basic Principles and Extentions. Seventh Edition. The Dryden Press. Foft Worth.

Pappas, J.L., dan M. Hirsehiy. 1995. Ekonomi Manajerial. Jilid 2. Binaputra Aksara. Jakarta. 
JURNAL चERRNOSAINS | VOL 9, NO.1, Desember 2019; 68-76

Pindyck, R.S., dan D.L. Rubinfeld. 2001. Econometrics Models and Economic Forecast. McGraw-Hill. New York.

Samuelson, P.A., dan W.D. Nordhaus. 2001. Microeconomics. Seventeenth Edition. McGraw-Hill Irwin. Boston.

Soekartawi. 1994. Prinsip Dasar Manajemen Pemasaran Hasil-hasil Pertanian. Teori dan Aplikasinya. Rajawali Press. Jakarta.
Weng, C.K. 2005. Best-Developed Practices and Sustainable Development of The Oil Palm Industry. Journal of Oil Palm Research, 17; 124-135.

Yotopoulus, P.A., dan J.B. Nugent. 1976. Economics of Development Empirical Investigations. Harper and Row Publishers. New York. 